\title{
Autumn migration of soaring birds in North Dobrogea, Romania: a study with implications for wind farm development
}

\author{
Attilla Fülöp ${ }^{1,2, *}$, Lörinc Bărbos ${ }^{1}$, GÁbor M. Bóné1, Szilárd J. \\ Daróczi ${ }^{1}$, Luca A. Dehelean ${ }^{1}$, RéKa B. Kiss ${ }^{1}$, István Kovács ${ }^{1}$, \\ AtTila NAGY ${ }^{1}$, TAMÁs PAPP ${ }^{1}$
}

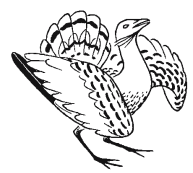

Attila Fülöp, Lőrinc Bărbos, Gábor M. Bóné, Szilárd J. Daróczi, Luca A. Dehelean, Réka B. Kiss, István Kovács, Attila Nagy, Tamás Papp 2012. Termikelő madarak őszi vonulása Észak-Dobrudzsában, Romániában: szempontok a szélerőmű parkok tervezéséhez. - Ornis Hungarica 20(2): 73-85.

\begin{abstract}
In Dobrogea, a core area for wind energy exploitation in Romania, existing knowledge regarding the intensity and pattern of bird migration is limited. In the absence of enumerated data, wind farms may be constructed in areas where large aggregations of migrants pass. In this study we recorded the intensity of the autumn migration of soaring birds in three locations within the Măcin Mountains, where wind farms are planned to be built. The locations chosen were at Văcăreni, Greci and Cerna villages. Furthermore we categorized all migrating individuals as threatened or non-threatened by the planned wind farms, based on their migration routes and height at local scale. At Văcăreni 4.716 individuals were counted, 3.394 raptors and 1.322 non-raptors, at Greci 2.387 individuals, 2.064 raptors and 323 non-raptors, and finally at Cerna, 5.268 individuals, 4.529 raptors and 739 non-raptors. At all three sites a significant proportion of birds, both raptors and non-raptors, were found to be threatened by the proposed wind farms. At Văcăreni $68.33 \%$ of raptors and $84.95 \%$ of non-raptors were at threat, at Greci $44.48 \%$ and $54.18 \%$ respectively, and at Cerna $59.37 \%$ and $94.86 \%$. As such we conclude that intensive migration occurs in North Dobrogea and wind farms would have a considerable negative impact on migrants in the studied areas.
\end{abstract}

Keywords: Măcin Mountains, migration corridor, raptors, wind energy, impact

Összefoglalás A madárvonulás intenzitásáról és mintázatáról Dobrudzsa területéről, mely egy kulcsfontosságú régiót jelent Románia számára, a szélenergia hasznosítása szempontjából csekély mennyiségú ismerettel rendelkezünk. A megfelelő információk hiányában a szélerőmü parkokat olyan területekre építhetik, ahol jelentős madár tömegek vonulnak el. Vizsgálatunkban a termikelő madarak őszi vonulását követtük a Măcin-hegység térségében, Văcăreni, Greci és Cerna települések határában, ahova a közeljövőben szélerőmű parkokat terveznek létesíteni. Az átvonuló egyedeket megszámoltuk, majd minden madár esetében megállapítottuk, összehasonlítva a vonulási útvonalát és magasságát a tervezett szélerőművek hatáskörzetével, hogy veszélyeztetett-e vagy sem a tervezett a szélturbinák által. Văcăreni-nél összesen 4716 egyedet észleltünk, 3394 ragadozót és 1322 nem ragadozót, Greci-nél 2387 egyedet, 2064 ragadozót és 323 nem ragadozót, és végül Cerna-nál 5268 egyedet, 4529 ragadozót és 739 nem ragadozót. Văcăreni-nél a ragadozók $68,33 \%$-a és a nem ragadozók $84,95 \%$-a vonult a veszélyes zónában, Greci-nél a ragadozók 44,48\%-a, a nem ragadozók 54,18\%-a, Cerna-nál a ragadozók 59,37\%-a, valamint a nem ragadozók 94,86\%-a repült át a veszélyes területen. Eredményeink alapján megállapíthatjuk, hogy Észak-Dobrudzsában jelentős őszi madárvonulás figyelhető meg, valamint a tervezett szélerőmü parkok jelentős kockázatot jelentenének a vonuló madarakra, ha megépülnének.

Kulcsszavak: Măcin-hegység, vonulási folyosó, ragadozók, szélenergia, veszélyforrás

${ }^{1}$ Milvus Group - Bird and Nature Protection Association, Crinului street 22, 540620 Târgu Mureș, Romania, e-mail: fafeldolgozo@gmail.com

${ }^{2}$ MTA-DE "Lendület” Behavioural Ecology Research Group, Department of Evolutionary Zoology and Human Biology, University of Debrecen, Egyetem tér 1, 4032 Debrecen, Egyetem tér 1., Hungary

* Correspondence to Attila Fülöp: e-mail: attila.fulop@milvus.ro, address: Milvus Group - Bird and Nature Protection Association, Crinului street 22, 540620 Târgu Mureş, Romania 


\section{Introduction}

The move to alternative energy sources has become one of the most important strategies in the European Union for the reduction of greenhouse gas emissions (Nagy \& Körmendi 2012). Along with solar power, hydroelectric power and geothermal energy, wind is an important renewable energy source which, when exploited through wind turbines, can produce electricity with minimal carbon emissions. Currently wind energy provides for $5.3 \%$ of the EU's energy consumption. However, this is set to rise steeply over the next two decades as the EU moves towards its target of generating $28.5 \%$ of its electricity usage by 2030 , according to some scenarios (EWEA 2011). This implies intensive proliferation of wind farms, and already a constant increase can be spotted all over Europe, including Romania, and inside Romania especially in Dobrogea.

Dobrogea is a region situated in the South-Eastern part of the country, between the Danube River and the Black Sea. It is characterized by an arid climate and windy weather, which shows a high intensity over the whole period of the year (Lungu et al. 2009). Due to its climate, Dobrogea constitutes a priority area for Romania to exploit wind energy (RWEA 2011) and as such the number of wind farms has increased significantly in this region in the last few years, with the total capacity of the approved projects until January 2012 reaching 5000 MW power (CN Transelectrica SA 2012).

Although wind farms are generally recognized as a 'green' energy source with various benefits, several adverse effects of wind far$\mathrm{ms}$ on flying animals (e.g. birds and bats) can be highlighted, which cannot be neglected (reviewed by Drewitt \& Langston 2006, Hötker et al. 2006, Kunz et al. 2007, Drewitt
\& Langston 2008). As a primary impact on birds, (1) wind farms cause habitat disturbance, both during building (Pearce-Higgins et al. 2012) and during functioning (Garvin et al. 2011, Carrete et al. 2012, De Lucas et al. 2012). Beside habitat disturbance, (2) wind farms also produce a barrier-effect in the course of passing individuals (Drewitt \& Langston 2006, Pruett et al. 2009), and, (3) most significantly, there is a high risk of collision for flying animals with the moving rotor blades (Drewitt \& Langston 2006), which can occur both during local movements, or during migration. Thus sedentary and migrating individuals can be affected as well (Drewitt \& Langston 2006). Collision risk, hence mortality rate, of birds at wind farms can be highly variable over the year (De Lucas et al. 2008) and it depends on a wide range of factors, like bird species, number and behavior of individuals, flight strategy, migratory behavior, weather conditions and surface topography (reviewed by Drewitt \& Langston 2006, Drewitt \& Langston 2008), as well as from turbine height and elevation above sea level (De Lucas et al. 2008). It has been shown previously that the most affected groups are birds using the soaring-gliding flight style, like raptors (Garvin et al. 2011). Therefore, based on our present knowledge, the scenario with the highest collision risk would be a flock of soaring birds flying at the height of the wind farms in bad weather conditions, over a migration route (Kikuchi 2008).

Raptors and other soaring birds migrate over well-established migration routes (or migration corridors) and generally use geographical bottlenecks (e.g. Bosporus, Gibraltar, Suez) to cross large water surfaces (Ferguson-Lees \& Christie 2001). Over these migration routes and bottlenecks large concentrations of migrating birds can be counted (Newton 2008). In Romania, Dobrogea 
is defined as an important migration corridor for birds coming from the Northern- and North-Eastern part of Europe and heading to Africa through the Bosporus, following the Via Pontica flyway, a section of the Eurasian - East African Flyway which runs down the Western coast of the Black Sea (Domahidi et al. 2004, Newton 2008, Michev et al. 2012). Large numbers of birds pass every autumn over Dobrogea (Domahidi \& Komáromi 2004, Domahidi et al. 2004, Komáromi 2005, Milvus Group 2008, Pârâu 2011). The geographical distribution of the migrants is relatively uniform, however migration intensity tends to be more accentuated on the Western- and Eastern parts of the region (Milvus Group 2011).

In the present study we provide data on the magnitude of autumn migration of several raptors and other bird species in three different regions of North Dobrogea, all located within the area of Măcin Mountains, where wind farms are planned to be constructed in the near future. All three study sites are part of a Natura 2000 site (ROSPA0073) or are in the near vicinity of it, thus represent areas of high conservation priority. Beside the number of migrating individuals we try to assess the potential impact of wind farms on the migrants, based on the migration route and height of individuals compared to the operating range of wind turbines at local scale. Our study highlights the importance of this region as a migration corridor and the potential negative effect of the wind farms on migrants.

\section{Material and Methods}

\section{Species of interest}

We focused our study on several bird species which may be negatively influenced by the presence of wind farms in the course of their migration. Typically such groups include all raptors and other large-sized soaring birds (e.g. Storks, Pelicans, Cranes). Beside the enumerated taxa we also recorded the species belonging to the following groups: Cormorants, Herons, Geese, Ducks, Gulls and Pigeons. Most of these birds are large-sized, thus they can be detected and counted from long distances.

\section{Study sites}

We made our observations from three different count points simultaneously. Count points were located in the area of Măcin Mountains, in the vicinity of the villages of Văcăreni (N 45.265267 , E $\left.028.227751^{\circ}\right)$, Greci $\left(45.136395^{\circ}, \mathrm{E} 028.263373^{\circ}\right)$ and Cerna $\left(\mathrm{N} 45.068871^{\circ}, \mathrm{E} 028.346660^{\circ}\right)$. In all the three places wind farms are planned to be built with various number of wind turbines: 35 at Văcăreni (APM Tulcea 2011a, APM Tulcea 2011b, APM Tulcea 2011c, As Orimex New SRL 2011a, As Orimex New SRL 2012a), 24 at Greci (As Orimex New SRL 2011b, As Orimex New SRL 2012b, As Orimex New SRL 2012c) and 27 at Cerna (APM Tulcea 2011d, As Orimex New SRL 2011c, As Orimex New SRL 2013). Observation points were placed on the top of hills to have good visibility on the study areas and to maximize the chance to observe migrating birds over large distances (see Figure 1).

\section{General survey procedures}

We recorded the 'visible' migration of birds in the autumn of 2012 during two different periods, between 20-30 September and 5-14 October, summing 21 observation days in total. Survey periods were chosen 


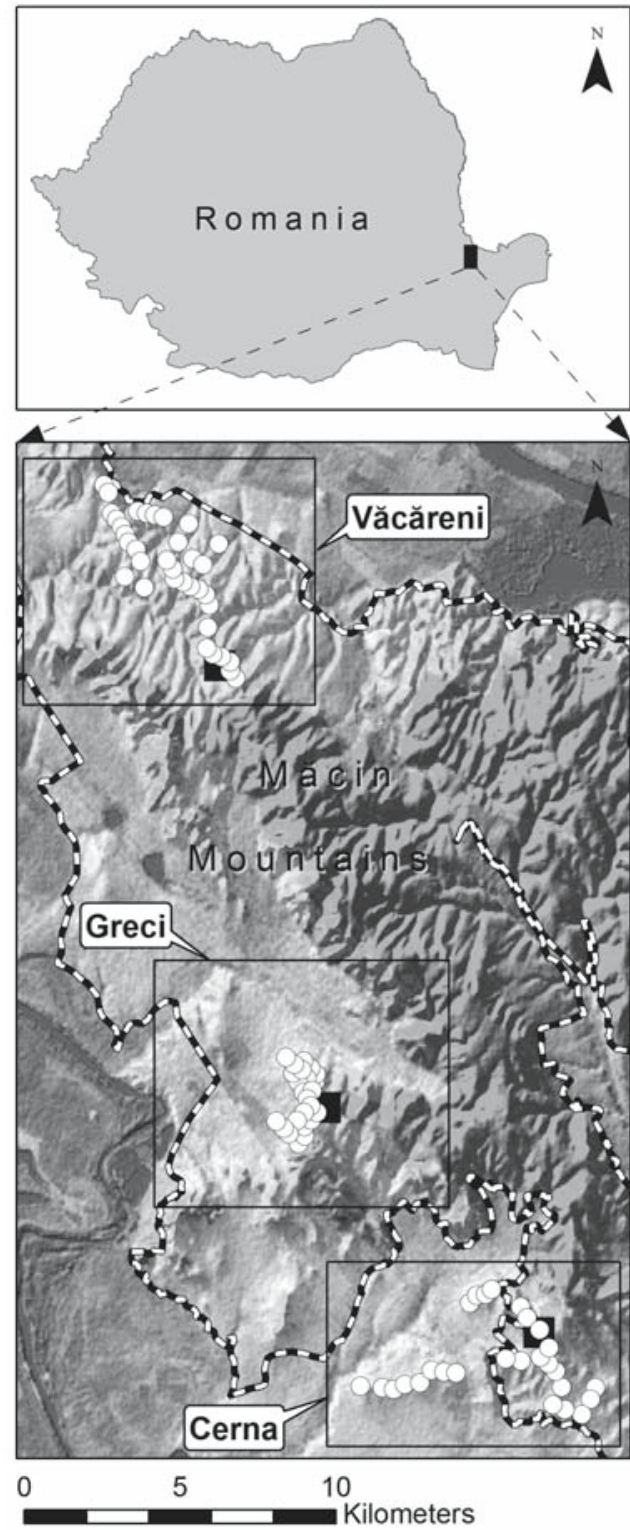

Legend

12 ROSPA0073 Măcin - Niculiţel
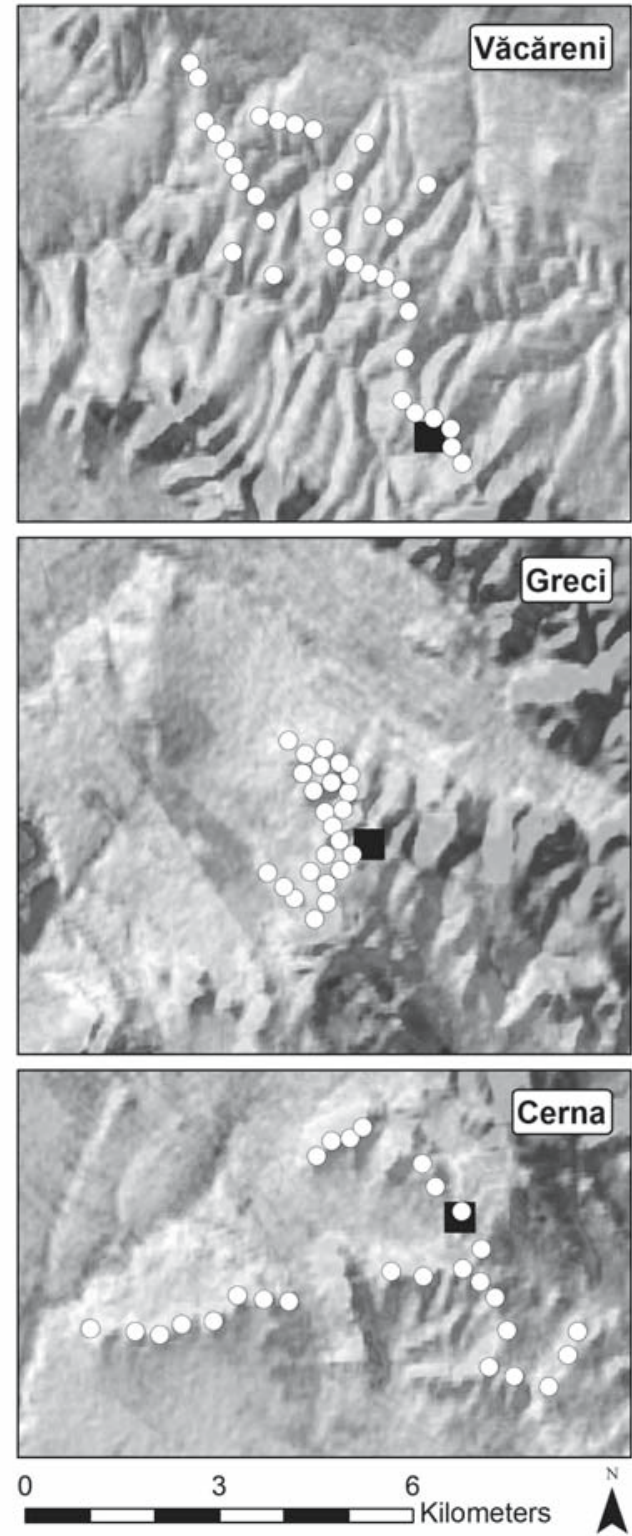

Planned wind turbines

ם Observation points

Figure 1. Map showing the location of the study sites in Măcin Mountains. A highlighted view of each site shows the positioning of the count points in relation to the distribution of the planned wind turbines and surface topography

1. ábra A vizsgált területek elhelyezkedése a Măcin-hegység térségében (bal oldal). Az egyes mintaterületeket külön-külön ábrázoló térkép, mely a megfigyelőpont elhelyezkedését szemlélteti a tervezett szélturbinák helyzetéhez és a felszín domborzatához viszonyítva (jobb oldal) 
to cover the migration peak of the two most abundant migrating raptors in Dobrogea in this period, the Lesser Spotted Eagle (Aquila pomarina) and the Common Buzzard (Buteo buteo) respectively (Pârâu 2011). According to previous studies (Domahidi et al. 2004, Pârâu 2011) the migration peak of the Lesser Spotted Eagles in the area of Măcin Mountains is in the second half of September. The abundance of migrating Common Buzzards fluctuates over time, but the highest numbers were recorded between 20 September and 15 October (Domahidi \& Komáromi 2004, Komáromi 2005, Pârâu 2011).

We carried out our observations every day between 9 AM and 6 PM according to the method described by Bird \& Bildstein (2007). During these hours 2-4 ornithologists were present on every survey point, actively searching for migratory birds arriving from the North, North-East or North-West, but without disregarding the other directions either. Surveyors were equipped with binoculars (Leica Ultravid HD 10×42) and spotting scopes (Kowa TSN-883, eyepieces 30× and 20-60×). Observations were suspended only in case of bad weather conditions (rain or fog), when the visibility decreased significantly and counting became impossible. We recorded all the observed migrating individuals or flocks in standard data sheets. Migrating birds were identified at species level. If accurate determination was impossible, birds were determined at genus level or marked as unknown. Unidentified raptors were noted using a common reference as 'Rapaces sp.'. Beside the number of individuals we recorded the flight direction, distance from the count point and presence or absence in the risk zone. Wandering individuals were also noted (e.g. birds coming from South).

\section{Safe zone and risk zone}

Within the three study sites we determined the risk zone and the safe zone. The risk zone was delimited as the total operation range of the planned wind turbines. This took into account the altitude gradient, ranging between 0-200 meters above the ground level, to give the approximate range of motion of an average wind turbine. Individuals flying within the described altitude limits inside the area of a wind farm are considered as presenting a high collision risk with operating wind turbines. The safe zone was defined as all the area outside of the planned wind farms, or the altitude $>200$ meters above ground inside the area of the wind farms, the height from which most migrating birds can safely cross above the wind farm area.

\section{Double counts and data manipulation}

Double counting inside the same study area was prevented by following every bird or flock during its transition over the region, heading mainly from North to South, from the moment of its first detection until the moment of disappearance. Double counting between the count points cannot be completely avoided due to the positioning of the points along an approximate North-South gradient. Although the count points were at relatively large distances from each other, overestimates in the total number of individuals cannot be excluded.

The number of observed migrants was summed and the proportion of threatened and non-threatened individuals was calculated in the case of every species at all the three count points separately. 


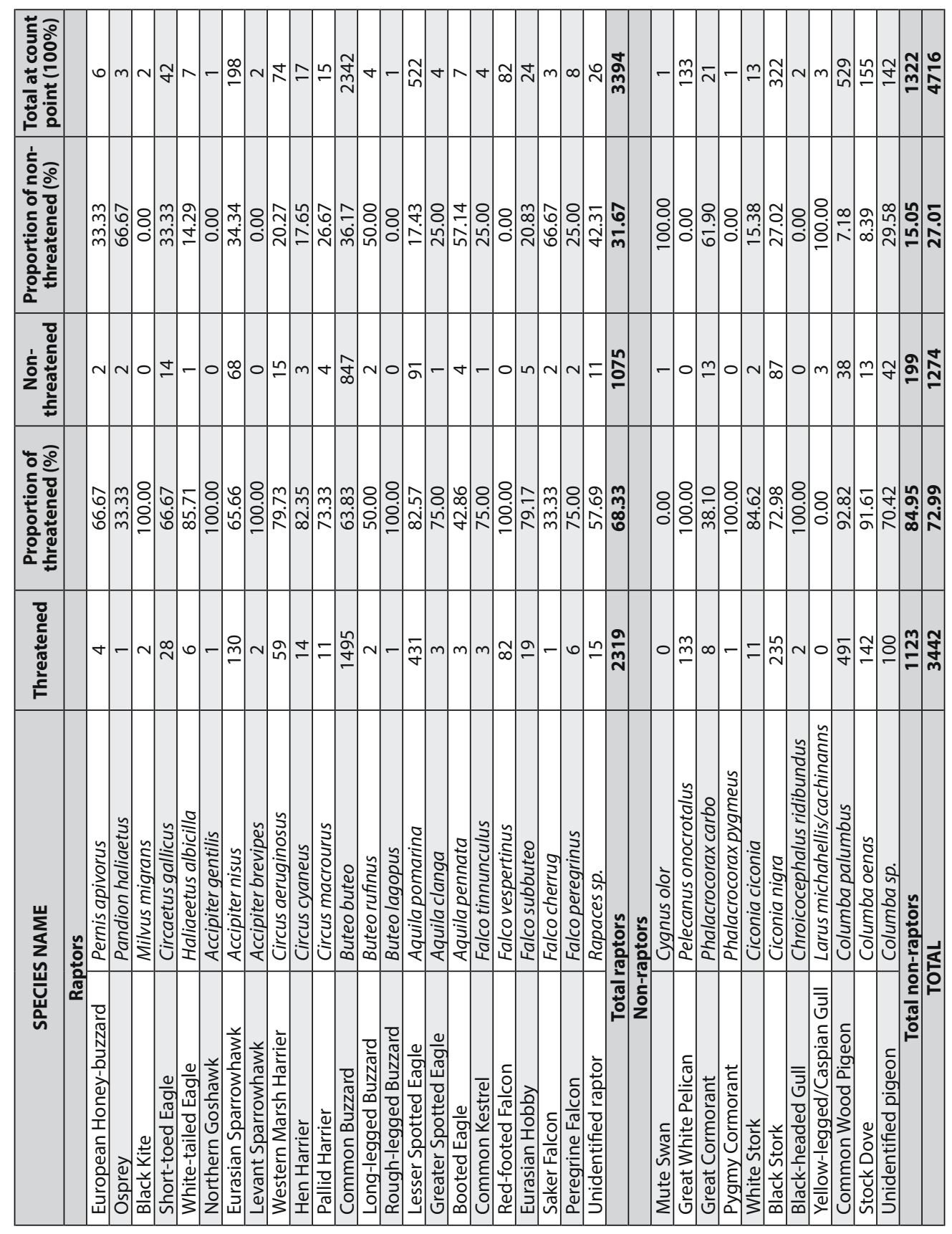

Table 1. Total number of migrating individuals recorded at Văcăreni study site during the full study period. The distribution of migrants between the risk zone (marked as Threatened) and safe zone (marked as Non-threatened) shows the potential impact of wind farms

1. táblázat A Văcăreni-i megfigyelőponton, a teljes vizsgálati időszak alatt rögzített, átvonuló egyedek összessége. Az egyedek eloszlása a veszélyes, illetve a nem veszélyes zónában a tervezett szélerőmű parkok potenciális hatását mutatják 
A. Fülöp, L. Bărbos, G. M. Bóné, Sz. J. Daróczi, L. A. Dehelean,

R. B. Kiss, I. Kovács, A. Nagy, T. Papp

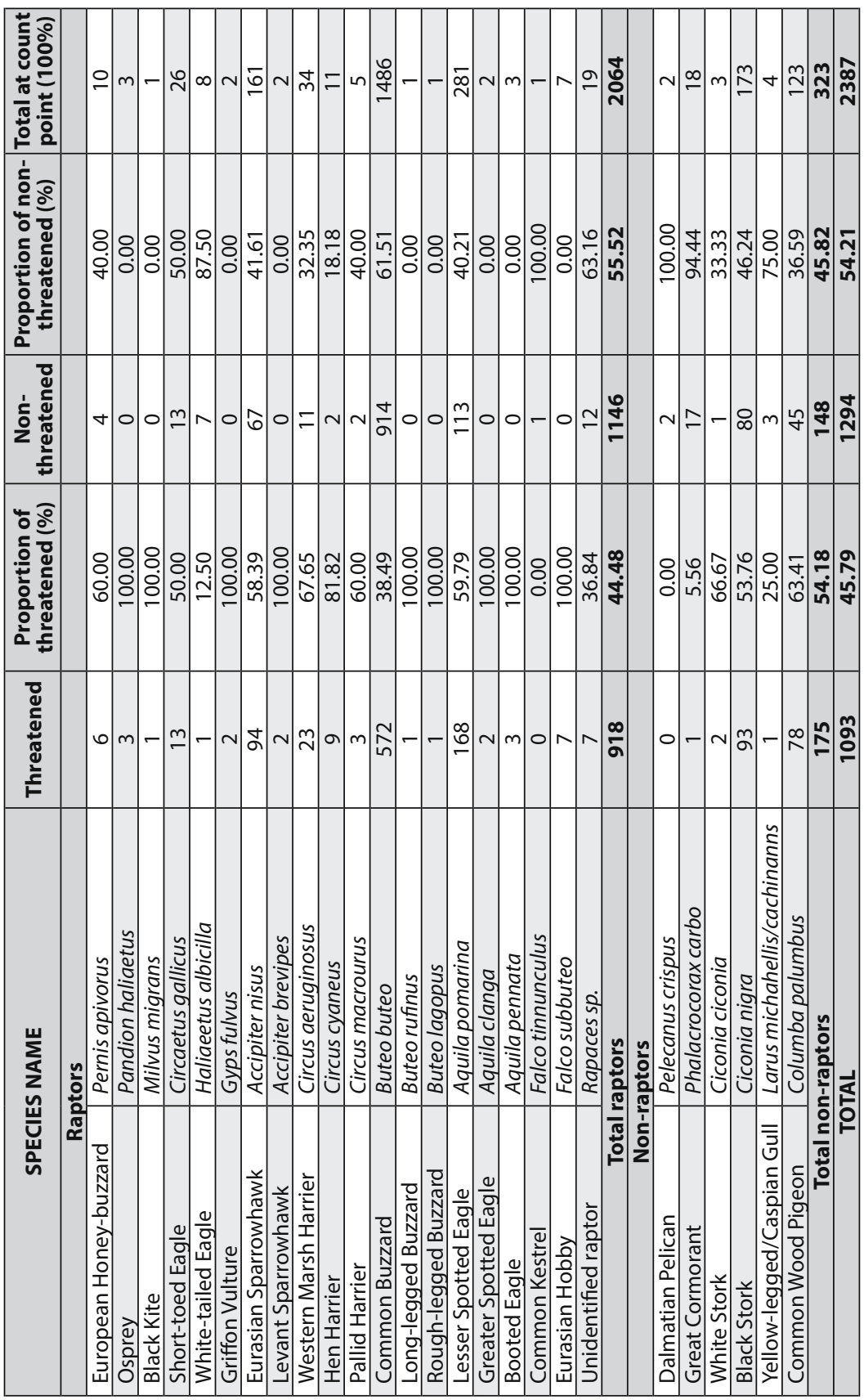

Table 2. Total number of migrating individuals recorded at Greci study site during the full study period. The distribution of migrants between the risk zone (marked as Threatened) and safe zone (marked as Non-threatened) shows the potential impact of wind farms

2. táblázat A Greci-i megfigyelőponton, a teljes vizsgálati időszak alatt rögzített, átvonuló egyedek összessége. Az egyedek eloszlása a veszélyes, illetve a nem veszélyes zónában a tervezett szélerőmű parkok potenciális hatását mutatják 


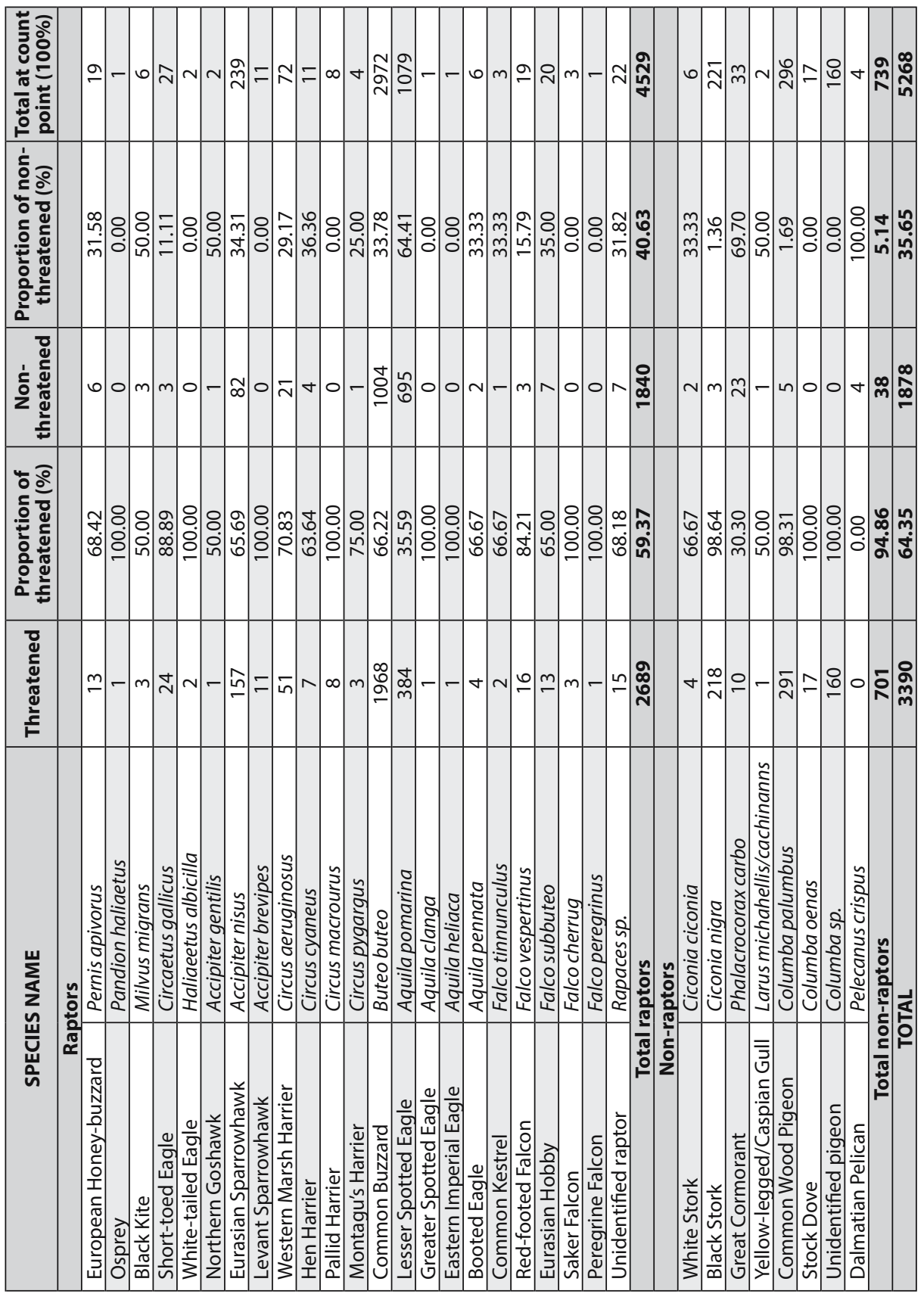

Table 3. Total number of migrating individuals recorded at Cerna study site during the full study period. The distribution of migrants between the risk zone (marked as Threatened) and safe zone (marked as Non-threatened) shows the potential impact of wind farms

3. táblázat A Cerna-i megfigyelőponton, a teljes vizsgálati időszak alatt rögzített, átvonuló egyedek összessége. Az egyedek eloszlása a veszélyes, illetve a nem veszélyes zónában a tervezett szélerőmű parkok potenciális hatását mutatják 


\section{Results}

At Văcăreni count point 4.716 birds were counted, 3.394 raptors and 1.322 non-raptors (Table 1). At Greci station a total of 2.387 birds were seen migrating, 2.064 raptors and 323 non-raptors (Table 2). The highest number of migrating individuals was registered at Cerna count point, with 5.268 individuals,
4.529 raptors and 739 non-raptors, counted (Table 3). At Văcăreni $68.33 \%$ of raptors and $84.95 \%$ of non-raptors migrated through the risk zone (Table 1). At Greci count station $44.48 \%$ of raptors and $54.18 \%$ of non-raptors migrated through the risk zone (Table 2), and finally at Cerna $59.37 \%$ of raptors and $94.86 \%$ of non-raptors migrated through the risk zone (Table 3) (Figure 2).

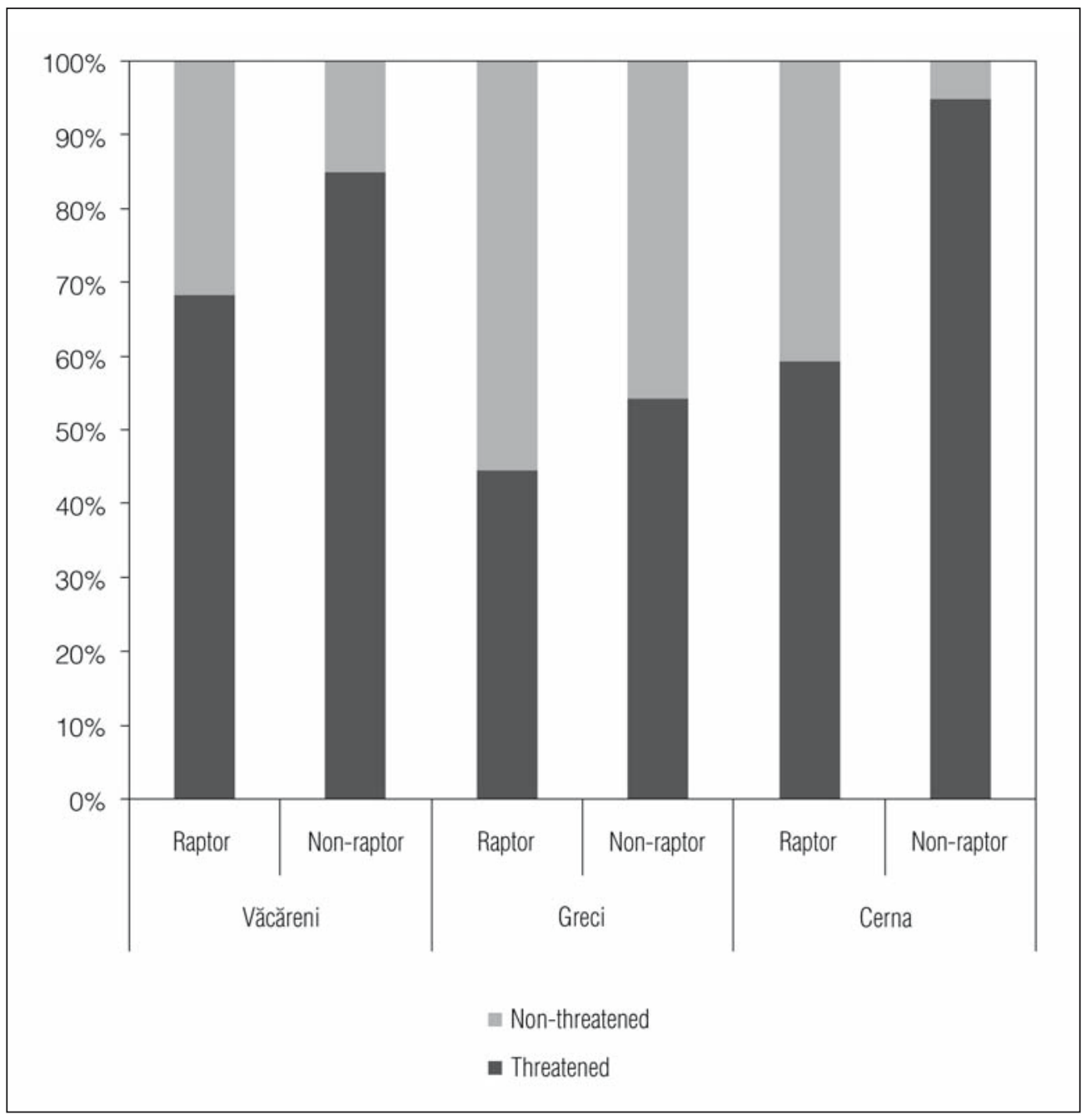

Figure 2. The proportion of threatened and non-threatened migrants observed at the three study sites during the full study period

2. ábra A teljes vizsgálati időszak alatt rögzített, a tervezett szélturbinák által veszélyeztetett, valamint nem veszélyeztetett átvonuló egyedek aránya a három mintaterületen 


\section{Discussion}

The impact of the intensive wind farming over the migrant birds is a subject prone to long debates between nature conservationists and entrepreneurs, especially in the case of Dobrogea, the core area for Romanian wind farming, where several interests overlap. On one side Romania, as a member state of the EU, has ambitious renewable energy targets to meet. But on the other side Dobrogea is a natural heritage with very high biodiversity, with $50.38 \%$ of its total surface area protected for nature conservation (MMSC 2011). Beside the interest of the government, the exploitation of renewable energy sources represents a highly profitable business opportunity for private companies. Not surprisingly, as a result of multiple conflicts of interest, the potential impact of wind farms on wildlife is generally underestimated in official reports, both intentionally and unintentionally, due to several reasons: lack of information about the different areas due to the limited number of studies available, lack of experts and superficiality of environmental impact assessment studies.

Our study aimed to fill this gap of information, at least partially, in the area of Măcin Mountains, which is also a Natura 2000 site. Our results demonstrate that (1) intensive migration occurs in Northern Dobrogea and (2) wind farms would have a significant negative impact on migrating birds, affecting a substantial part of the migrating individuals from our study areas. According to previous studies (Domahidi \& Komáromi 2004, Domahidi et al. 2004, Komáromi 2005, Milvus Group 2008, Pârâu 2011), we found that the Common Buzzard is the most abundant migrating raptor species. During this period of the year the $v u l$ - pinus subspecies of the Common Buzzard is the most numerous in this area, due to its different migratory strategy compared to the buteo subspecies, Buteo buteo vulpinus, a long term migrant that winters in Africa (Forsman 1999). The second most abundant raptor species was the Lesser Spotted Eagle. This species occurs also in large numbers in this area during late autumn, as does the Eurasian Sparrowhawk (Accipiter nisus), which was the third most abundant raptor (Domahidi \& Komáromi 2004, Domahidi et al. 2004, Komáromi 2005, Milvus Group 2008, Pârâu 2011). Previous studies demonstrated that the European Honey Buzzard (Pernis apivorus) migrates also in large numbers over Dobrogea (Milvus Group 2008). Hovewer the migration peak of the species is at the end of August - beginning of September (Cramp \& Simmons 1980). The most abundant non-raptors were Pigeons (Columba sp.) and Black Storks (Ciconia nigra). White and Black Storks migrate in large numbers over Dobrogea (Domahidi \& Komáromi 2004, Komáromi 2005). The migration peak of the White Storks (Ciconia ciconia) is during August, in the second part of the month until early September (Cramp \& Simmons 1977), which explains the small number of individuals counted during our study. In contrast, the migration peak of the Black Stork is one month later, at the end of September to early October (Cramp \& Simmons 1977), which explains the relative high proportion of Black Storks compared to other non-raptor species recorded during the study.

We have shown that a high proportion of both the raptors and non-raptors migrated across the risk area, therefore would be negatively affected by wind farms. In case of migratory birds the effect of wind farms can manifest in two ways: (1) either through 
a barrier-effect, or (2) by the increased risk of collision. Collision can be avoided by changing the flight trajectory or by increasing the flight height (De Lucas et al. 2004). But deviance from the optimal migration route increases the flight distance, which means elevated energy expenditure for the migrants (Hötker et al. 2006). The highest proportion of individuals migrating through the risk zone was at Văcăreni count station, at over $72 \%$. Soaring birds use the soaring-gliding flight style, hence they depend on the presence of thermals during their migration, which generally form on hillsides. But "wind strength is greatest at the break of the slope at ridge tops, so these are also the primary locations for wind energy' exploitation as well (Drewitt \& Langston 2008). Placement of wind turbines in these areas can be particularly dangerous, leading to increased levels of collision mortality for species that frequently use thermals to rise (Drewitt \& Langston 2008). The high proportion of birds entering the risk zone at Văcăreni count station might be explained by the presented phenomenon, as the study area covers a long slope on the Northern side of the Măcin Mountains and it is the transition zone between the floodplain of the Danube and the Northern ridge of the mountains. In the case of Greci and Cerna count stations the proportion of the individuals entering the risk zone was approximately $45 \%$ and $64 \%$ respectively, which is smaller compared to Văcăreni station, but still not negligible. The two count points are positioned in the South-Western part of the Măcin Mountains, thus birds might adopt a different migratory strategy at local scale as a consequence of the local surface topog- raphy, resulting a slightly smaller, but still considerable risk of the potential collision with wind turbines.

Based on our results we conclude that the planned wind farms in the three study areas may have a negative effect on migratory birds, especially at Văcăreni and Cerna stations, if constructed. Although our study fails to cover the whole autumn migration period, we have shown that large concentrations of birds migrate over North Dobrogea, one of the most abundant raptor being the Lesser Spotted Eagle, a species of international conservation interest. The significant part of this raptor's global population migrates along the Western coast of the Black Sea, over Dobrogea. In addition we have detected several species that migrated through the risk zone which, though represented in small numbers, are Red Listed (IUCN 2012) (e.g. Greater Spotted Eagle Aquila clanga, Eastern Imperial Eagle Aquila heliaca, Red-footed Falcon Falco vespertinus, Saker Falcon Falco cherrug). Also detected was Griffon Vulture (Gyps fulvus), a species which is a rarity for Romania, therefore giving our observation a high faunistic value. Further studies are needed to cover the whole migration period from mid-August to late October.

\section{Acknowledgements}

We are highly indebted to our volunteers who assisted us during field work: Clément Bougneux, Mareike Brix, Kinga Csiszér, Aude Deslandes, Anna Incze, Edgár Papp, Krisztina Sándor and Mihály Táncos. Luke Dale-Harris kindly improved our English. 


\section{References}

APM Tulcea. 2011a. Acord de mediu nr. 2397/11.01.2011 pentru construire parc de turbine eoliene, comuna Văcăreni, judeţul Tulcea - SC Global Legal Investments SRL. - (http://apmtl.anpm.ro), 30/05/2013. (In Romanian)

APM Tulcea. 2011b. Acord de mediu nr. 2398/12.01.2011 pentru construire parc de turbine eoliene, comuna Văcăreni, judeţul Tulcea - SC Energie Investments Group SRL. - (http://apmtl.anpm.ro), 30/05/2013. (In Romanian)

APM Tulcea. 2011c. Acord de mediu nr. 2399/12.01.2011 pentru construire parc de turbine eoliene, comuna Văcăreni, județul Tulcea - SC Intercom Design SRL. - (http://apmtl.anpm.ro), 30/05/2013. (In Romanian)

APM Tulcea. 2011d. Acord de mediu nr. 2400/03.02. 2011 pentru amplasare parc eolian, comuna Cerna, judeţul Tulcea - SC Energia Verde Ventuno SRL. - (http://apmtl.anpm.ro), 30/05/2013. (In Romanian)

As Orimex New SRL. 2011a. Raport de monitorizare a biodiversităţii pentru obiectivul: construire parc de turbine eoliene, extravilan comuna Văcăreni, județul Tulcea, perioada ianuarie 2011-octombrie 2011. - (http://apmtl.anpm.ro), 31/05/2013. (In Romanian)

As Orimex New SRL. 2011b. Raport de monitorizare a biodiversităţii pentru obiectivul: parc eolian şi amenajare drumuri, extravilan comuna Greci, judeţul Tulcea, perioada martie 2010-octombrie 2011. - (http://apmtl.anpm.ro), 31/05/2013. (In Romanian)

As Orimex New SRL. 2011c. Raport de monitorizare a biodiversităţii pentru obiectivul: parc eolian Cerna, comuna Cerna, judeţul Tulcea, perioada noiembrie 2009-octombrie 2011. - (http://apmtl. anpm.ro), 31/05/2013. (In Romanian)

As Orimex New SRL. 2012a. Raport de monitorizare a biodiversităţii pentru obiectivul: construire parc de turbine eoliene, extravilan comuna Văcăreni, judeţul Tulcea, perioada noiembrie 2011-iunie 2012. - (http://apmtl.anpm.ro), 31/05/2013. (In Romanian)

As Orimex New SRL. 2012b. Raport de monitorizare a biodiversităţii pentru obiectivul: parc eolian şi amenajare drumuri, extravilan comuna Greci, judeţul Tulcea, perioada noiembrie 2011-decembrie 2011. - (http://apmgl.anpm.ro), 31/05/2013. (In Romanian)

As Orimex New SRL. 2012c. Raport de monitorizare a biodiversităţii pentru obiectivul: parc eolian şi amenajare drumuri, extravilan comuna Greci, judeţul Tulcea, perioada ianuarie 2012-august 2012. - (http://apmgl.anpm.ro), 31/05/2013. (In Romanian)

As Orimex New SRL. 2013. Raport de monitorizare a biodiversităţii pentru obiectivul: parc eolian Cerna, comuna Cerna, judeţul Tulcea, perioada aprilie 2012-martie 2013. - (http://apmtl.anpm.ro), 31/05/2013. (In Romanian)

Bird, D. M. \& Bildstein, K. L. 2007. Raptor research and management techniques. - Hancock House Publishers, Surrey

Carrete, M., Sánchez-Zapata, J. A., Benítez, J. R., Lobón, M., Montoya, F. \& Donázar, J. 2012. Mortality at wind-farms is positively related to largescale distribution and aggregation in griffon vultures. - Biological Conservation 145: 102-108. doi:10.1016/j.biocon.2011.10.017

CN Transelectrica SA. 2012. Situaţia contractelor de racordare la 27 ianuarie 2012. - (www.transelectrica.ro), 03/05/2013. (In Romanian)

Cramp, S. \& Simmons, K. E. L. 1977. The Birds of the Western Palearctic, Volume I. - Oxford University Press, Oxford

Cramp, S. \& Simmons, K. E. L. 1980. The Birds of the Western Palearctic, Volume II. - Oxford University Press, Oxford

De Lucas, M., Janss, G. F. E. \& Ferrer, M. 2004. The effects of a wind farm on birds in a migration point: the Strait of Gibraltar. - Biodiversity Conservation 13: 395-407. doi: 10.1023/B: BIOC.0000006507.22024.93

De Lucas, M., Janss, G. F. E., Whitfield, D. P. \& Ferrer, M. 2008. Collision fatality of raptors in wind farms does not depend on raptor abundance. - Journal of Applied Ecolology 45: 1695-1703. doi: 10.1111/j.1365-2664.2008.01549.x

De Lucas, M., Ferrer, M., Bechard, M. J. \& Muñoz, A. R. 2012. Griffon Vulture mortality at wind farms in southern Spain: distribution of fatalities and active mitigation measures. - Biological Conservation 147: 184-189. doi:10.1016/ j.biocon.2011.12.029

Domahidi, Z. \& Komáromi, I. 2004. Monitorizarea migraţiei păsărilor răpitoare diurne din Munţii Măcinului. - Migrans 6(4): 1-3. (In Romanian)

Domahidi, Z., Zeitz, R. \& Daróczi, J. Sz. 2004. Raptor migration as a conservation opportunity: first full-season migration counts in South-East Romania. - In: Chancellor, R. D., \& Meyburg, B.U. (eds.) Raptors Worldwide - Proceedings of the $6^{\text {th }}$ World Conference on Birds of Prey and Owls, May 2003, Budapest, Hungary 
Drewitt, A. \& Langston, R. H. W. 2006. Assessing the impacts of wind farms on birds. - In: Wind, Fire and Water: Renewable Energy and Birds. Ibis 148(Suppl. 1): 29-42. doi: 10.1111/j.1474919X.2006.00516.X

Drewitt, A. \& Langston, R. H. W. 2008. Collision effects of wind-power generators and other obstacles on birds. - Annals of the New York Academy of Sciences 1134: 233-266. doi: 10.1196/annals.1439.015

EWEA. 2011. Pure Power. Wind energy targets for 2020 and 2030. A report by the European Wind Energy Association. - (www.ewea.org), 30/01/2013.

Ferguson-Lees, J. \& Christie, D. A. 2001. Raptors of the World. - Helm Identification Guides, London

Forsman, D. 1999. The Raptors of Europe and the Middle East: A Handbook of Field Identification. - T \& AD Poyser, London

Garvin, J. C., Jennelle, C. S., Drake, D. \& Grodsky, S. M. 2011. Responses of raptors to a windfarm. - Journal of Applied Ecology 48: 199-209. doi: 10.1111/j.1365-2664.2010.01912.x

Hötker, H., Thomsen, K.-M. \& Jeromin, H. 2006. Impacts on biodiversity of exploitation of renewable energy sources: the example of birds and bats - facts, gaps in knowledge, demands for further research, and ornithological guidelines for the development of renewable energy exploitation. - Michael-Otto-Institut im NABU, Bergenhusen

IUCN. 2012. The IUCN Red List of Threatened Species. Version 2012.2. - (www.iucnredlist.org), $17 / 10 / 2012$.

Kikuchi, R. 2008. Adverse impacts of wind power generation on collision behaviour of birds and anti-predator behaviour of squirrels. - Journal of Nature Conservation 16: 44-55. doi: 10.1016/ j.jnc.2007.11.001

Komáromi, I. 2005. Tabăra pentru observarea migraţiei de toamnă a păsărilor răpitoare diurne. - Migrans 7(4): 1-2. (In Romanian)

Kunz, T. H., Arnett, E. B., Erickson, W. P., Hoar, A. R., Johnson, G. D., Larkin, R. P., Strickland, M. D., Thresher, R. W. \& Tuttle, M. D. 2007. Ecological impacts of wind energy development on bats: questions, research needs, and hypotheses. - Frontiers in Ecology and the Environment 5:
315-324. http://dx.doi.org/10.1890/1540-9295(2 007)5[315:EIOWED]2.0.CO;2

Lungu, M., Panaitescu, L., Albu, A. \& Niţă, S. 2009. The strong winds - climatic hazards to the agricultural crops in Dobrudja. - RJAS 41(1): 64-67.

Michev, T. M., Profirov, L. A., Karaivanov, N. P. \& Michev, B. T. 2012. Migration of soaring birds over Bulgaria. - Acta Zoologica Bulgarica 64(1): 33-41.

MMSC. 2011. Ministerul Mediului Şi Schimbărilor Climatice - Arii naturale protejate. - (www.mmediu.ro), 12/02/2013. (In Romanian)

Milvus Group. 2008. Măcin Mountains raptor migration watchsite 2002-2007. - (www.milvus.ro), $31 / 01 / 2013$.

Milvus Group. 2011. Autumn raptor migration study in Dobrogea - 2010, 2011. - (www.milvus.ro), $31 / 01 / 2013$.

Nagy, K. \& Körmendi, K. 2012. Use of renewable energy sources in light of the 'new energy strategy for Europe 2011-2020'. - Applied Energy 96: 393-399. http://dx.doi.org/10.1016/j.apenergy.2012.02.066

Newton, I. 2008. The ecology of bird migration. - Academic Press, London

Pârâu, L. 2011. Migraţia de toamnă a răpitoarelor diurne (Clasa Aves, Accipitriformes) în Munţii Măcinului. - BSc thesis, 'Alexandru Ioan Cuza' University (In Romanian)

Pearce-Higgins, J. W., Stephen, L., Douse, A. \& Langston, R. H. W. 2012. Greater impacts of wind farms on bird populations during construction than subsequent operation: results of a multi-site and multi-species analysis. - Journal of Applied Ecology 49: 386-394. doi: 10.1111/j.13652664.2012.02110.x

Pruett, C. L., Patten, M. A. \& Wolfe, D. H. 2009. Avoidance behaviour by prairie grouse: implications for wind energy development. - Conservation Biology 23: 1253-1259. doi: 10.1111/j.15231739.2009.01254.x

RWEA. 2011. Wind energy in Romania. A report by the Romanian Wind Energy Association. - (www. rwea.ro), 12/02/2013. 